Cem Horozoglu, Seyda Demirkol, Aysegul Verim, Dilara Sonmez, Saime Sürmen, Ozlem Kucukhuseyin, Umit Zeybek and Ilhan Yaylim*

\title{
Is there any relationship between LGALS3 gene variations and histopathological criteria in laryngeal squamous cell carcinoma (LSCC)?
}

\section{Larinksin skuamöz hücreli karsinomunda LGALS3 gen varyasyonlarıyla histopatolojik kriterler arasında bir ilişki var $\mathrm{mı}$ ?}

https://doi.org/10.1515/tjb-2020-0177

Received April 10, 2020; accepted May 15, 2021;

published online June 9,2021

\section{Abstract}

Objectives: Genetic variations of LGALS3 (Galectin-3) were found to be associated with treatment resistance, mortality, recurrence, high tumor volume and multiple tumor involvement in solid organ cancers. The modulators of extracellular matrix (ECM), which is a dynamic factor in the larynx tissue with high biomechanical and regenerating

*Corresponding author: Ithan Yaylim, Department of Molecular Medicine, Aziz Sancar Institute of Experimental Medicine, Istanbul University, Vakif Gureba Cad., Sehremini-Fatih, 34093 Istanbul, Turkey, Phone: +90 2124142000, Fax: +90 2125324171,

E-mail: ilhanyaylim@gmail.com

Cem Horozoglu, Department of Medical Biochemistry, Faculty of Medicine, Biruni University, Istanbul, Turkey. https://orcid.org/00000001-8998-2028

Seyda Demirkol, Department of Molecular Biology, Faculty of Engineering and Natural Sciences, Biruni University, Istanbul, Turkey; and Department of Molecular Medicine, Aziz Sancar Institute of Experimental Medicine, Istanbul University, Istanbul, Turkey. https://orcid.org/0000-0003-1211-0736

Aysegul Verim, Department of Otorhinolaryngology/Head and Neck Surgery, Haydarpasa Numune Education and Research Hospital, Istanbul, Turkey. https://orcid.org/0000-0002-6649-0837 Dilara Sonmez, Saime Sürmen, Ozlem Kucukhuseyin and Umit Zeybek, Department of Molecular Medicine, Aziz Sancar Institute of Experimental Medicine, Istanbul University, Istanbul, Turkey. https://orcid.org/0000-0002-4962-5330 (D. Sonmez). https://orcid.org/0000-0001-6298-5026 (0. Kucukhuseyin) ability, can play an important role. We aimed to investigate the relationship between the genetic variants of LGALS3, one of these modulators, with Laryngeal Squamous Cell Carcinoma (LSCC).

Methods: LGALS3 gene variations were genotyped by PCR-RFLP method using genomic DNA samples obtained from peripheral blood samples of 74 patients diagnosed with LSCC and 94 healthy controls.

Results: The $C$ allele carriage for the Rs4652 genetic variant was found to be higher $(\mathrm{p}=0.017)$ in patients with LSCC. Statistical relationships were found between homozygous genotypes of this variant (CC/AA) with advanced tumor stage $(\mathrm{p}=0.017)$ and presence of reflux $(\mathrm{p}=0.036)$. CC genotype for rs4644 was found to be higher in cases with positive family history $(\mathrm{p}=0.036)$.

Conclusions: Our findings of LGALS3 gene variants, which are also found to be associated with other solid cancers, suggest that they may play a role in LSCC pathophysiology similarly.

Keywords: galectin-3; LGALS3; LSCC; rs4644; rs4652.

\section{öz}

Amaç: LGALS3'ün (Galectin-3) genetik varyasyonlarının, solid organ kanserlerinde tedaviye direnç, ölüm oranı, nüks, yüksek tümör hacmi ve çoklu tümör tutulumu ile ilişkili olduğu bulunmuştur. Biyomekanik açıdan rejenerasyon kabiliyeti yüksek larinks dokusunda, dinamik bir faktör olarak ECM modülatörleri önemli rol oynayabilir. $\mathrm{Bu}$ modülatörlerden LGALS3'ün genetik varyantları ile LSCC (Laringeal Skuamöz Hücreli Karsinom) arasındaki ilişkiyi araştırmayı amaçladık. 
Gereç ve Yöntem: LSCC tanısı almış 74 hasta ve 94 sağlıklı kontrolün periferik kan örneklerinden elde edilen genomik DNA örnekleri kullanılarak LGALS3'ün genetik varyantları PCR-RFLP yöntemiyle genotiplendirildi.

Bulgular: LSCC'li hastalarda Rs4652 genetik varyantı için C aleli taşıyıcılığının daha yüksek olduğu tespit edildi $(\mathrm{p}=0.017)$. Bu varyantın homozigot genotipleri (CC/AA) ile ileri tümör evresi $(\mathrm{p}=0.017)$ ve reflü varlığı $(\mathrm{p}=0.036)$ arasında istatistiksel ilişkiler bulundu. Aile öyküsü pozitif olan olgularda ise rs4644 genetik varyantı için CC genotipinin diğer genotiplere göre daha yüksek olduğu tespit edildi ( $\mathrm{p}=0,036)$.

Sonuç: Diğer solid kanserler tipleriyle de ilişkisi tespit edilen LGALS3 gen varyantlarına ait bulgularımız benzer şekilde LSCC patofizyolojisinde rol oynayabileceğini göstermektedir.

Anahtar Kelimeler: Galektin-3; LGALS3; LSCC; rs4644; rs4652.

\section{Introduction}

Biomolecules that make up the extracellular matrix (ECM) are examined under three basic classes as structural proteins, specialized proteins and proteoglycans. Each biomolecule is synthesized by tissue-forming cells and neighboring cells, and causes a series of morphological changes in target cells through autocrine, paracrine and similar signal transduction pathways. The responses in the target cell may be in the direction of proliferation, differentiation, adhesion. Recent studies show that ECM has approximately 300 proteins and these play a role in remodeling and modulation of ECM [1]. Proteoglycans are peptide chains containing covalently linked glycosaminoglycans (GAGs). They contain 95\% carbohydrate and 5\% protein in their structure. There are seven types of GAG: hyaluronic acid, chondroitin sulfate, keratan sulfate I and II, heparin, heparan sulfate and dermatan sulfate. GAGs are heterogeneous polysaccharides containing long, linear and repeating disaccharide units. These disaccharide units are galactose, galactosamine, Nasetylgalactosamine4-sulfate and galacturonic acid [2].

Saccharides have important roles in both ECM energy metabolism regulation and glycoprotein/glycolipid synthesis. For this reason, lectins that play a role in the transfer of sugar groups in ECM are critical molecules in modulation. Galectins are proteins that bind $\beta$-galactosides such as $\mathrm{N}$-acetyllactosamine present in $\mathrm{N}$-linked and O-linked glycoproteins. Sixteen galectin types have been identified in humans, some of which interact with proteins by carbohydrate binding, while others can interact without carbohydrate binding. Galectins can often be both negative and positive modulators of the same processes, suggesting plasticity in isoforms, posttranslational modifications or comolecules present, and/or differences in localization. These possible changes give galectins the ability to make both positive and negative regulation [3].

Galectin-3 is a chimera protein, which has a structure quite different from other galectins. Galectin-3 has the C-terminal Carbohydrate Recognition Domain (CRD) as well as the N-terminal CRD. While the N-terminal CRD of galectin-3 can induce apoptosis by activating caspase 9 , apoptosis can be suppressed by a different antibody binding of this region. The antiapoptotic effect is dependent on phosphorylation of serine 6 in galectin-3 and the intracellular presence of galectin-3 [4, 5]. This phosphorylation is critical in regulating the binding of galectin-3 to ligands. The contribution of galectin-3 to the apoptotic process changes depending on the phosphorylation/dephosphorylation ratio of serine [6].

Human galectin-3 is a $35-\mathrm{kDa}$ protein that is coded by a single gene, LGALS3, located on chromosome 14. Galectin3 expression changes directly affect ECM and cell communication and play a role in different stages of carcinogenesis [7]. Rs4644 and rs 4652 are among the most common single nucleotide polymorphisms (SNP) sites found in the exon 3 of LGALS3, causing a missense change in the codon. In these studies, it was found that these variants were related to the functional role and galectin-3 protein levels [8]. Rs4644 encodes histidine instead of proline with a C> A-G exchange at position 191, while Rs4652 is in position 292 which causes a proline coding instead of threonine [9].

They found that rs4644 variant may be associated with poor progression in Brazilian patients with gastric cancer [10]. In a study conducted in a case group with gastric carcinoma, Southeast Chinese cases were not associated with rs4644 variant, but CA/AA genotypes of rs4652 were found to be at higher risk than CC genotype [11]. In the glioblastoma cell line, the allele A for rs4644 variant was found to be associated with resistance to chemotherapy and radiotherapy [12]. CC/CA genotypes for rs 4652 in cervical cancer cases in the Chinese population were high in the patient group and were associated with low 5 year survival [13].

CC genotype for rs4644 variant was found to be associated with mucinous component involvement in Turkish colorectal cancer patients [14]. In the study in which the functional effect of the rs4644 variant was examined in gastric cancer cell lines and patient tissue samples, it was found that the AA genotype increased the nuclear accumulation of Beta catenin and transcriptional activity more than the AC genotype [9]. In breast cancer cell culture modeling, it was found that those carrying His64 (G or A alleles) for Rs4644 were susceptible to TRAIL and 
doxorubicin resistant, whereas those who had Pro64 (C allele) were resistant to TRAIL and susceptible to doxorubicin [15]. While the protective effect of His64 wild type genotype was shown for Rs4644 in patients with brachytherapy in German prostate cancer, this effect was found to be higher especially in patients diagnosed before 60 years of age [16]. Homozygous histidine-bearing genotypes (GG or AA) were found to be higher in patients with Caucasian and Asian breast cancer than in the control group [17]. In an American research group, rs4644 and AA genotype and rs4652 were found to be associated with high tumor volume in non-small cell lung cancer cases, and CC and AC genotypes of rs4652 were associated with mortality risk. At the same time, the AA genotype of rs 4644 has been associated with multiple locus tumor involvement and recurrence [18].

The two most common types of head and neck cancers are head and neck squamous cell carcinoma (HNSCC) and laryngeal squamous cell carcinoma (LSCC). Despite surgical and oncologic procedures, LSCC is a high-risk cancer type due to rapid distant metastasis at early stage and low 5 year low right rate. Smoking, alcohol use and HPV infection play a major role in the etiology of LSCC, and many molecular markers have been shown to be etiologically important [19]. LSCC is clinically and histopathologically characterized by highly aggressive malignant cells, and it is important to identify new molecular markers. In this respect, examining the molecules that play a role in ECM in laryngeal tissues, which have a highly dynamic biomechanical and regenerative ability, may be helpful in understanding laryngeal carcinogenesis. We aimed to investigate the effects of genetic variations of LGALS3 (Galectin-3), which has important roles in the modulation of ECM, in LSCC.

\section{Methods}

\section{Patients and genotyping}

A group of 74 patients diagnosed as LSCC in the clinic of Otorhinolaryngology/Head and Neck Surgery, Haydarpaşa Numune Hospital were formed. The healthy control group consisted of 97 (age and healthy volunteers who were not diagnosed with cancer). The patients and controls ranged in age from 43 to 85 years (mean age - standard deviation, $61.32 \pm 8.8$ years and $60.18 \pm 7.6$ years), with 72 males, two females. The study design, protocols and informed content was approved by both the Haydarpasa Numune Hospital Clinical Research Ethics Committee (Decree No. HNEAH-KAEK-2017/KK/06).

\section{Genotyping and pathological examinations}

Surgically resected tumor specimens of patients with laryngeal cancer were fixed in $10 \%$ formaldehyde. Hematoxylin-eosin staining was performed on sections obtained after pathological tissue follow-up procedures. Macroscopic and microscopic findings were evaluated according to Larynx Staging Form - 8th Ed and histopathological characteristics were determined. Peripheral blood samples were taken from the patient and control groups and genomic DNA isolation was performed according to the manufacturer's instructions by QIAamp DNA blood mini-kits (Qiagen, Valencia, CA). PCR was performed using Forward: $5^{\prime}$-TTA TCC TGG ACA GGC ACC TC- $3^{\prime}$ (common), Reverse: 5'-AAG GAA TGC CAT CTC ACC AG-3' (rs4652) and 5'-AAG GAA GC CACC ACC AG-3' (rs4644) for the rs4644 and rs4652 gene variants of LGALS3.

PCR products were cut into fragments with restriction enzymes, which are specific to its cut points corresponding to nucleotides in the DNA sequence. Allele and genotype distributions according to fragment lengths were determined after PCR-RFLP procedure. In PCR Products, restriction enzyme digestion was performed with BsW1 for StyI rs4652 for rs4644. After enzyme cutting, genotyping was performed according to band patterns by $2 \%$ agarose gel electrophoresis. Accordingly, 201 bp as CC genotype, 204, 170, 31 bp as CA genotype, and 170, 31 bp as AA genotype were evaluated for Rs4644. For Rs4652, 201 bp as CC genotype, 201, 134 and 67 bp as CA genotype, and 134, $67 \mathrm{bp}$ as AA genotype were evaluated.

\section{Statistics}

SPSS 20.0 software (SPPS Inc., Chicago, IL, USA) was used for statistical evaluation of our study data. Genotype and allele distributions of LGALS3 gene variants were performed using Chi square and t test. Multivariate logistic regression analysis was performed in the analysis of models based on multiple risk factors.

\section{Results}

The genotype and allele distributions are shown in Table 1. There was no statistical difference between the patient and control groups in terms of age and gender $(p>0.05)$. There was no difference between the genotypes $(p=0.364)$ and alleles ( $\mathrm{p}=0.145$ ) between the patient and control groups in the rs4644 variant of LGALS3. For the rs4652 variant of LGALS3, no statistically significant difference was found between the patient and control in terms of genotypes $(\mathrm{p}=0.053)$.

However, C allele frequency for rs 4652 was found to be higher in the patient group compared to the control group $(p=0.017)$. The frequency of homozygous genotypes (CC/AA) of Rs4652 was found to be higher in advanced tumor stage compared to early tumor stage $(\mathrm{p}=0.017)$. Similarly, the frequency of homozygous genotypes was found to be higher in patients with reflux than patients without reflux $(\mathrm{p}=0.036)$. The frequency of CC genotype carriage of Rs4644 was found to be higher in patients with positive family history of laryngeal cancer than those with negative family history of laryngeal cancer $(p=0.036)$. 
Table 1: LGALS3 allele and genotype distribution in study groups.

\begin{tabular}{lrrr}
\hline Genotypes/alleles & $\begin{array}{r}\text { LSCC group } \\
(\mathbf{n = 7 4 )}\end{array}$ & $\begin{array}{r}\text { Control group } \\
(\mathbf{n}=97)\end{array}$ & $\mathrm{p}$-Value \\
& Frequency, $\%$ & Frequency, $\%$ & \\
\hline rs4644 & & & \\
CC & $35(47.3 \%)$ & $55(56.7 \%)$ & $\mathrm{p}=0.364$ \\
CA & $30(40.5 \%)$ & $35(36.1 \%)$ & \\
AA & $9(12.2 \%)$ & $7(7.2 \%)$ & \\
C allele & $100(67.6 \%)$ & $145(74.7 \%)$ & $\mathrm{p}=0.145$ \\
A allele & $48(32.4 \%)$ & $49(25.3 \%)$ & \\
rs4652 & & & \\
AA & $22(29.7 \%)$ & $44(45.4 \%)$ & $\mathrm{p}=0.053$ \\
AC & $38(51.4 \%)$ & $44(45.4 \%)$ & \\
CC & $14(18.9 \%)$ & $9(9.3 \%)$ & \\
A allele & $82(55.4 \%)$ & $132(68 \%)$ & $\mathrm{p}=0.017$ \\
C allele & $66(44.6 \%)$ & $62(32 \%)$ & \\
\hline
\end{tabular}

Genotype distributions according to histopathological criteria are shown in Table 2.

According to the logistic regression results, a statistically significant difference was found between the patient group and the control group in the model composed of $\mathrm{C}$ allele transport, positive family history and smoking groups for the Rs4652 variant ( $\mathrm{p}=0.034)$. Similarly, there was a statistically significant difference between advanced tumor stage and early tumor stage according to logistic regression modeling of Rs4652 positive family history and $\geq 65$ age groups in patients with $C$ allele $(p=0.015)$. The results related to logistic regression groups are shown in Table 3.

\section{Discussion}

Although no relation was found in the rs4644 variant of LGALS3 compared to the control group in patients with laryngeal cancer, CC genotype carriage of rs4644 was found to be significant in patients with positive family history ( $\mathrm{p}=0.034)$. Apart from our study, peer data on rs4644 variant in LSCC is not seen in our literature reviews. In contrast, CC genotype carriage for rs 464 was detected in Turkish patients with colorectal cancers [14]. This variant may be a negative factor in tumor progression independent of cancer type due to the common gene pool.

In Chinese patients with gastric cancers where we have a similar gene pool for most genotypes, no correlation was found for rs4644 [11]. However, the A allele or AA genotype carriage for rs 4644 was found to be related in patients with received prostate cancer [16], patients with Caucasian breast cancer [17], and patients with Texas of non-small cell lung cancer [18]. The differences in genotypes and alleles in the studies may be due to the different types of cancers, as well as from the study groups formed from breeds with different gene pools. At this point, the results of a functional genotyping study by Mazurek et al. While carrying the A allele for rs4644 variant in breast cancer cell lines caused resistance to

Table 2: LGALS3 genotype distribution according to histopathological and clinicopathological features in LSCC group.

\begin{tabular}{|c|c|c|c|c|c|c|}
\hline \multirow[t]{2}{*}{ Histopathology/clinicopathology } & \multicolumn{3}{|c|}{ LGALS3 rs4644 } & \multicolumn{3}{|c|}{ LGALS3 rs4652 } \\
\hline & CC & CA & AA & AA & AC & CC \\
\hline Advanced tumor stage (T3+T4) & $21(40.4 \%)$ & $24(46.2 \%)$ & $7(13.5 \%)$ & $17(32.7 \%)$ & $22(42.3 \%)$ & $13(25 \%)^{\star \star}$ \\
\hline Early tumor stage $(\mathrm{T} 1+\mathrm{T} 2)$ & $14(63.6 \%)$ & $6(27.3 \%)$ & $2(9.1 \%)$ & $5(22.7 \%)$ & $16(72.7 \%)$ & $1(4.5 \%)^{\star \star}$ \\
\hline Lymph node ratio & $13(44.8 \%)$ & $11(37.9 \%)$ & $5(17.2 \%)$ & $8(27.6 \%)$ & $14(48.3 \%)$ & 7 (24.1\%) \\
\hline \multicolumn{7}{|l|}{ Positive (n1, n2, n3) } \\
\hline Lymph node ratio & $22(48.9 \%)$ & $19(42.2 \%)$ & $4(8.9 \%)$ & $14(31.1 \%)$ & $24(53.3 \%)$ & $7(15.6 \%)$ \\
\hline \multicolumn{7}{|l|}{ Negative (n0) } \\
\hline Distant metastasis positive & $1(100 \%)$ & $0(0 \%)$ & $0(0 \%)$ & $1(100 \%)$ & $0(0 \%)$ & $0(0 \%)$ \\
\hline Distance metastasis negative & $34(46.6 \%)$ & 30 (41.1\%) & $9(12.3 \%)$ & $21(28.8 \%)$ & $38(52.1 \%)$ & $14(19.2 \%)$ \\
\hline Positive reflux & $15(53.6 \%)$ & 9 (32.1\%) & $4(14.3 \%)$ & $10(35.7 \%)^{\star \star \star}$ & $10(35.7 \%)$ & $8(28.6 \%)^{\star \star \star}$ \\
\hline Negative reflux & $20(43.5 \%)$ & $21(45.7 \%)$ & $5(10.9 \%)$ & $12(26.1 \%)^{\star \star \star}$ & $28(60.9 \%)$ & $6(13 \%)^{\star \star \star}$ \\
\hline Positive perineural invasion & $8(61.5 \%)$ & $4(30.8 \%)$ & $1(7.7 \%)$ & $4(30.8 \%)$ & $6(46.2 \%)$ & $3(23.1 \%)$ \\
\hline Negative perineural invasion & $27(44.3 \%)$ & $26(42.6 \%)$ & $8(13 \%)$ & $18(29.5 \%)$ & $32(52.5 \%)$ & $11(18 \%)$ \\
\hline Smokers & $23(46.9 \%)$ & $20(40.8 \%)$ & $6(12.2 \%)$ & $17(34.7 \%)$ & $23(46.9 \%)$ & $9(18.4 \%)$ \\
\hline Non-smokers & $12(48 \%)$ & 10 (40\%) & $3(12 \%)$ & $5(20 \%)$ & $15(60 \%)$ & $5(20 \%)$ \\
\hline Alcohol consumption (light and moderate drinkers) & $20(35 \%)$ & $25(45 \%)$ & $11(20 \%)$ & $14(25 \%)$ & $22(40 \%)$ & $20(35 \%)$ \\
\hline Alcohol consumption (abstainers) & $8(60 \%)$ & $3(20 \%)$ & $3(20 \%)$ & $6(40 \%)$ & $5(40 \%)$ & $3(20 \%)$ \\
\hline Differentiation (well and medium) & $20(43.5 \%)$ & $21(45.7 \%)$ & $5(10.9 \%)$ & $14(30.4 \%)$ & $25(54.3 \%)$ & $7(15.2 \%)$ \\
\hline Differentiation (poor) & $6(60 \%)$ & $2(20 \%)$ & $2(20 \%)$ & $4(40 \%)$ & $3(30 \%)$ & $3(30 \%)$ \\
\hline Positive family history & $9(75 \%)^{\star}$ & $2(16.7 \%)$ & $1(8.3 \%)$ & $4(33.3 \%)$ & $6(50 \%)$ & $2(16.7 \%)$ \\
\hline Negative family history & $26(41.9 \%)^{\star}$ & $28(45.2 \%)$ & $8(12.9 \%)$ & $18(29 \%)$ & $32(51.6 \%)$ & $12(19.4 \%)$ \\
\hline
\end{tabular}

This value* is $p=0.036$; ${ }^{\star \star}$ is $p=0.030 ;{ }^{* \star \star}$ is $p=0.036$. 
Table 3: Logistic regression models for LGALS3 rs4652 variant in LSCC group.

\begin{tabular}{lrrr}
\hline Logistic regression models & p-Value & Odd ratio & $95 \% \mathrm{Cl}$ \\
\hline Patients vs. controls & & & \\
LGALS3 - rs4652 for C allele & $\mathbf{0 . 0 3 4}$ & $\mathbf{3 . 1 5 5}$ & $\mathbf{1 . 0 9 0 - 9 . 1 3 4}$ \\
Family history of cancer & 0.998 & 0.000 & 0.000 \\
Smoking & 0.997 & 0.000 & 0.000 \\
Late tumor stage vs. early tumor stage & & \\
LGALS3 - rs4652 for C allele & $\mathbf{0 . 0 1 5}$ & 4.329 & $\mathbf{1 . 3 3 5 - 1 4 . 0 3 6}$ \\
Family history of cancer & 0.910 & 0.916 & $0.199-4.210$ \\
Smoking & 0.739 & 1.223 & $0.374-3.996$ \\
65 and 65+ age & 0.328 & 0.542 & $0.159-1.848$ \\
\hline
\end{tabular}

doxorubicin, which is one of the cancer chemotherapeutics, C allele transport was found to be related to susceptibility to doxorubicin. Similarly, in the same study, it was found that $\mathrm{G}$ or A allele carriers were susceptible to TRAIL, one of the important regulators of apoptosis, whereas $\mathrm{C}$ allele carriers were found to be resistant to TRAIL signal transduction [15]. This suggests that the rs4644 variant may play regulation at different stages of common multistep carcinogenesis in different types of cancer rather than in the patient control group. This point should be examined in detail by functional studies and it is important to investigate the possible therapeutic target.

In our results, we found that $C$ alleles and genotypes of rs4652 are important for clinicopathological findings such as tumor stage and positive family history and reflux. We also observed that this significance was maintained in the logistic regression model based on age, smoking and family history. For Rs4652, the CC genotype was associated with poor survival [13] in Chinese cervical cancers, and with tumor volume size and mortality in non-small cell lung cancer with Texas [18]. Similarly, there was a correlation between CA genotype and Chinese gastric cancer cases [11]. In the literature, studies on rs4652 suggest that the relationship between $C$ allele and related genotypes in different populations and cancers is important both in the risk of disease independent from other factors and in tumor biology. More than one risk factor for laryngeal cancer and the fact that carrying $\mathrm{C}$ allele in the patient group in logistic regression results was significant in advanced tumor stage support the studies of Lan et al.

Although phosphorylation mechanisms are important in the modulation of galectin-3, it is known that $\mathrm{pH}$ changes occurring with the contribution of the cellular microenvironment are at least as effective in binding to ligand as phosphorylation [19]. In addition to known C-terminal serine phosphorylation in the activation of galactin-3, it was determined that N-terminal tyrosine 107 may play a key role in prostate cancer cases [20]. We mentioned that rs4644 variation of LGALS3 may cause histidine > proline change and rs4652 may cause theronin > proline change. It is among the results obtained in our study that CC/AA homozygous genotypes, in which the same amino acid is encoded in both alleles at Rs4652, are associated with the early tumor stage. Accordingly, it can be thought that the CA genotype may be a secondary mutation in the tumor tissue in advanced cancer stages. In order to investigate this hypothesis, advanced functional analyzes are needed in a sample of heterozygous individuals. It was determined in our study group that the CC (wild type) genotype of Rs4644 is associated with positive family history. It may be beneficial to study DNA samples extracted from tumor tissue to reveal whether there is a preserved genotype that may play a key role in the pathological process in patients with hereditary laryngeal cancer.

On the clinical axis, SNPs can be associated as an independent risk or protective factor. Especially, SNPs within the exon, exon-intron junction region and promoter region can cause changes in protein levels or conformation [21]. The rs4644 and rs4652 that we examined in our study are SNPs showing exon localization. Failure to examine the reflections of SNPs, which we identified as risk factors, to serum protein level, not showing protein or m-RNA level in tumor tissue, and the presence of a low number of patients are among the limitation factors of our study.

HPV infection has been identified among the etiological factors in the development of oropharyngeal cancer for years. However, there is speculative information on whether HPV will play a role in the development of laryngeal cancer. Therefore, HPV is not routinely investigated among risk factors for laryngeal cancer development. However, not knowing the HPV status of the cases in our study can be said as a limitation factor.

On the other hand, the statistical relationships we have detected in the genotype axis will contribute to researchers who are interested in the molecular mechanism of laryngeal cancers and will carry out functional studies.

Research funding: The present study was supported by a grant from the Scientific Research Projects Coordination Unit of Istanbul University (BYP-2019-32095).

Competing interests: The authors declare that they have no competing interest.

\section{References}

1. Yue B. Biology of the extracellular matrix: an overview. J Glaucoma 2014;23:S20-3.

2. Theocharis AD, Skandalis SS, Gialeli C, Karamanos NK. Extracellular matrix structure. Adv Drug Deliv Rev 2016;97: 4-27. 
3. Brinchmann MF, Patel DM, Iversen MH. The role of galectins as modulators of metabolism and inflammation. Mediat Inflamm 2018;2018:9186940.

4. Xue H, Liu L, Zhao Z, Zhang Z, Guan Y, Cheng H, et al. The $\mathrm{N}$-terminal tail coordinates with carbohydrate recognition domain to mediate galectin-3 induced apoptosis in T cells. Oncotarget 2017;8:49824-38.

5. Yoshii T, Fukumori T, Honjo Y, Inohara H, Kim HR, Raz A. Galectin-3 phosphorylation is required for its anti-apoptotic function and cell cycle arrest. J Biol Chem 2002;277:6852-7.

6. Mazurek N, Sun YJ, Price JE, Ramdas L, Schober W, Nangia-Makker $P$, et al. Phosphorylation of galectin-3 contributes to malignant transformation of human epithelial cells via modulation of unique sets of genes. Canc Res 2005;65:10767-75.

7. Nakahara S, Raz A. Regulation of cancer-related gene expression by galectin-3 and the molecular mechanism of its nuclear import pathway. Canc Metastasis Rev 2007;26:605-10.

8. Hu CY, Chang SK, Wu CS, Tsai W-I, Hsu P-N. Galectin-3 gene (LGALS3) +292 C allele is a genetic predisposition factor for rheumatoid arthritis in Taiwan. Clin Rheumatol 2011;30: 1227-33.

9. Kim SJ, Shin JY, Cheong TC, Choi I-J, Lee YS, Park SH, et al. Galectin-3 germline variant at position 191 enhances nuclear accumulation and activation of $\beta$-catenin in gastric cancer. Clin Exp Metastasis 2011;28:743-50.

10. Furuya TK, Jacob CE, Tomitão MTP, Camacho LCC, Ramos MFKP, Eluf-Neto J, et al. Association between polymorphisms in inflammatory response-related genes and the susceptibility, progression and prognosis of the diffuse histological subtype of gastric cancer. Genes 2018;13:9.

11. Shi Y, Lin X, Chen G, Yan J, Ying M, Zheng X, et al. Galectin-3 rs4652 A>C polymorphism is associated with the risk of gastric carcinoma and P-glycoprotein expression level. Oncol Lett 2017; 14:8144-9.

12. Wang $H$, Song $X$, Huang $Q, X u T$, Yun D, Wang $Y$, et al. LGALS3 promotes treatment resistance in glioblastoma and is associated with tumor risk and prognosis. Cancer Epidemiol Biomark Prev 2019;28:760-9.

13. Fang SQ, Feng YM, Li M. Correlations of galectin-3 gene polymorphisms with risk and prognosis of cervical cancer in Chinese populations: a case-control study. Oncol Res Treat 2017; 40:533-9.

14. Korkmaz G, Horozoglu C, Arıkan S, Gural Z, Sağlam EK, Turan S, et al. LGALS3 and AXIN1 gene variants playing role in the Wnt/ $\beta$-catenin signaling pathway are associated with mucinous component and tumor size in colorectal cancer. Bosn J Basic Med Sci 2016;4:108-13.

15. Mazurek N, Byrd JC, Sun Y, Ueno S, Bresalier RS. A galectin-3 sequence polymorphism confers TRAIL sensitivity to human breast cancer cells. Cancer 2011;117:4375-80.

16. Meyer A, Coinac I, Bogdanova N, Dubrowinskaja N, Turmanov N, Haubold S, et al. Apoptosis gene polymorphisms and risk of prostate cancer: a hospital-based study of German patients treated with brachytherapy. Urol Oncol 2013;31:74-81.

17. Balan V, Nangia-Makker P, Schwartz AG, Jung YS, Tait L, Hogan V, et al. Racial disparity in breast cancer and functional germ line mutation in galectin-3 (rs4644): a pilot study. Canc Res 2008;68: $10045-50$

18. Lan M, Xu T, Gomez DR, Jeter MD, Nguyen QN, Deng W, Lin SH, et al. Association between LGALS3 gene polymorphisms and survival in non-small cell lung cancer patients treated with definitive radiation therapy. Int J Radiat Oncol Biol Phys 2017;98: 249-50.

19. Yang QQ, Deng YF. Long non-coding RNAs as novel biomarkers and therapeutic targets in head and neck cancers. Int 2014;7: 1286-92.

20. Balan V, Wang Y, Nangia-Makker P, Kho D, Bajaj M, Smith D, et al. Galectin-3: a possible complementary marker to the PSA blood test. Oncotarget 2013;4:542-9.

21. De Boer RA, Verweij N, van Veldhuisen DJ, Westra H-J, Bakker SJL, Gansevoort RT, et al. A genome-wide association study of circulating galectin-3. PloS One 2012;7:e47385. 